\title{
Flood protection effect of the existing and projected reservoirs in the Amur River basin: evaluation by the hydrological modeling system
}

\author{
Y. Motovilov ${ }^{1}$, V. Danilov-Danilyan ${ }^{1}$, E. Dod ${ }^{2}$, and A. Kalugin ${ }^{1}$ \\ ${ }^{1}$ Water Problems Institute of RAS, Moscow, Russia \\ ${ }^{2}$ RusHydro, Russian Hydroelectricity Company, Moscow, Russia \\ Correspondence to: Y. Motovilov (motol@ pochta.ru)
}

Received: 11 March 2015 - Accepted: 11 March 2015 - Published: 11 June 2015

\begin{abstract}
Hydrological modeling system was developed as a tool addressed supporting flood risk management by the existing and projected reservoirs in the Amur River basin. The system includes the physically-based semidistributed model of runoff generation ECOMAG coupled with a hydrodynamic MIKE-11 model to simulate channel flow in the main river. The case study was carried out for the middle part of the Amur River where large reservoirs are located on the Zeya and Bureya Rivers. The models were calibrated and validated using streamflow measuruments at the different gauges of the main river and its tributaries. Numerical experiments were carried out to assess the effect of the existing Zeya and Bureya reservoirs regulation on $850 \mathrm{~km}$ stretch of the middle Amur River stage. It was shown that in the absence of the reservoirs, the water levels downstream of the Zeya and Bureya Rivers would be $0.5-1.5 \mathrm{~m}$ higher than the levels measured during the disastrous flood of 2013. Similar experiments were carried out to assess possible flood protection effect of new projected reservoirs on the Zeya and Bureya Rivers.
\end{abstract}

\section{Introduction}

The creation of science-based strategic program of flood protection in flood hazard regions is related to flood risk assessment, risk management for flood hazard areas of river systems, and its implementation; it should include, first of all, planning of structural measures to protect the population and economic facilities, including the creation of flood control reservoirs, construction of dams, etc. The planning and development of such technical measures should be based on modern hydroinformatics technologies, considering different downstream flood protection goals for decision support (Petersen, 2009). Instrumental basis of these technologies can be physically-based models of hydrological processes in river basins (Gelfan and Motovilov, 2014).

In this paper, the results of the application of hydroinformatics support computer technology for flood risk management to assess the effects of existing and projected reservoirs on the major tributaries of the Middle Amur - the Zeya and Bureya rivers, on altering the flood behavior in downstream areas and flood properties on the $850 \mathrm{~km}$ stretch of the Middle Amur River stage (Fig. 1) are discussed. The technology consists of three interrelated components: (1) a physicallybased semi-distributed model of runoff generation ECOMAG (Motovilov et al., 1999a, b), (2) a one-dimensional hydrodynamic model of unsteady water flow in the river channel (MIKE-11), and (3) a database of hydrometeorological and cartographic information and appropriate systems to manage these databases. First, an ensemble of runoff hydrographs at the mouths of major tributaries of the main river are simulated by the ECOMAG model depending on the different scenarios of meteorological forcing, the location and technical parameters of existing and projected reservoirs on these tributaries. Then, the MIKE-11 hydrodynamic model calculates discharges and water levels of main river. The scenarios of runoff hydrographs in the mouths of tributaries simulated by the ECOMAG model are assigned as a lateral inflow to the main river. The appraisals of the flood protection effects of existing and projected reservoirs are carried out 
Table 1. Nash and Sutcliffe Efficiency $R_{\mathrm{NS}}^{2}$ of the ECOMAG model verification in the Zeya and Bureya River basins.

\begin{tabular}{lrcc}
\hline & $\begin{array}{r}\text { Catchment } \\
\text { area } \\
\left(\mathrm{km}^{2}\right)\end{array}$ & $\begin{array}{c}\text { Calibration } \\
2000 \\
(2005)-2009\end{array}$ & $\begin{array}{c}\text { Validation } \\
2010-2013\end{array}$ \\
\hline Inflow into the Zeya Reservoir & 83800 & 0.72 & 0.80 \\
Mouth of the Zeya River & 229000 & 0.79 & 0.86 \\
Inflow into the Bureya Reservoir & 65200 & 0.80 & 0.80 \\
\hline
\end{tabular}

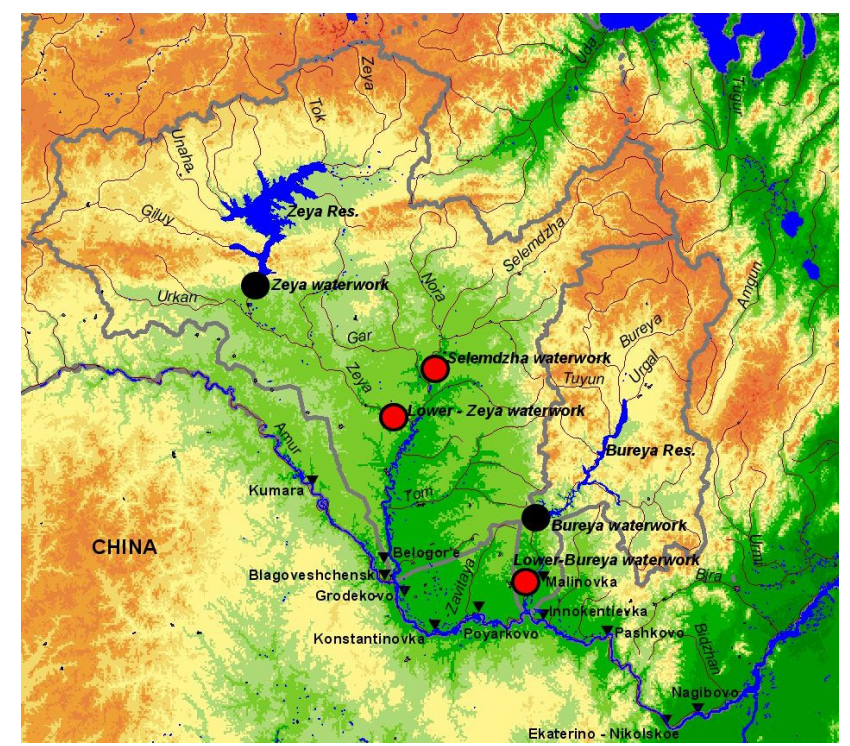

Figure 1. Location of the existing (black circles), projected and under construction (red circles) waterworks in the Zeya and Bureya River basins.

based on analysis of the differences in a flood behavior in downstream areas.

\section{Validation of the models in the Zeya and Bureya basins and the Middle Amur}

Runoff simulations in the Zeya and Bureya River basins, numerical experiments to assess the flood control effect of existing and projected reservoirs on the hydrological regime at the mouths of these tributaries of the Amur River were carried out on the basis of the ECOMAG model. Calibration of model parameters for the Zeya River basin was done against data on water inflow in the Zeya Reservoir and measured runoff at the mouth of the Zeya River during 2000-2009, and for the Bureya River basin - against data on water inflow in the Burea Reservoir from 2005 (after filling reservoir) to 2009. Unfortunately, runoff measurements in the mouth of the Burea River absent. Validation of the models was carried out for the period 2010-2013. The results of model tests in the Zeya and Bureya basins in most cases show good quality modeling (Table 1) (Danilov-Danilyan et al., 2014).
One-dimensional hydrodynamic model of flood wave movement MIKE-11, built for the 850-km stretch of the Middle Amur River (Fig. 1), has been implemented using standard morphometric and hydrometric data. The morphometric characteristics of the channel were based on pilot charts. Floodplain topography was obtained by digital topographic maps at the scale of 1:100,000. Forty cross sections were constructed at the study segment of the Amur River (about one cross section per $20 \mathrm{~km}$ along the channel). As the boundary conditions at the upper boundary of the model segment of the Amur River - Kumara gauge (Fig. 1) - daily water discharges were specified. At the lower boundary water levels at Nagibovo gauge were specified. As the result the hydrodynamic model describes the channel of the Amur River from Kumara gauge to a place near confluence of the Songhua River. Calibration of Manning roughness coefficient in the channel and on the floodplain was carried out according to the observational data on water levels and discharges for the period 1975-1999 at the Amur River gauges, shown in Fig. 1. Validation of the model was carried out for the period 2000-2011 and 2013. The results of model tests showed good quality modeling of discharges and water levels at the study segment of the Amur River (Table 2).

\section{Evaluation of the impact of flow regulation by existing the Zeya and Bureya reservoirs on the hydrological regime of the Middle Amur and its tributaries}

Figure 2 shows the results of two numerical experiments using the ECOMAG model to assess the impact of flow regulation by existing the Zeya and Bureya reservoirs to reduce the maximum discharges at the mouths of these rivers during the disastrous flood in 2013. In the first experiment simulation of runoff hydrograph at the mouths of the Zeya and Bureya Rivers was performed taking into account the actual discharges from reservoirs; in the second scenario actual inflow into the reservoirs at the sections of the Zeya and Bureya waterworks was specified as the discharge through these waterworks, i.e. as if runoff had not been regulated by the Zeya and Bureya reservoirs. Figure 2 clearly show flood control function of these reservoirs in 2013.

The simulation results with the MIKE-11 model for these two scenarios inflows into the Amur from the Zeya and $\mathrm{Bu}-$ 
Table 2. Nash and Sutcliffe Efficiency $R_{\mathrm{NS}}^{2}$ of the MIKE-11 model verification in the stretch of the Middle Amur River.

\begin{tabular}{lcrrccc}
\hline $\begin{array}{l}\text { Gauging } \\
\text { stations }\end{array}$ & $\begin{array}{c}\text { Length } \\
\text { from } \\
\text { gauge } \\
\text { Kumara } \\
(\mathrm{km})\end{array}$ & $\begin{array}{r}\text { Catchment } \\
\text { area } \\
\left(\mathrm{km}^{2}\right)\end{array}$ & $\begin{array}{r}\text { Hazard } \\
\text { water } \\
\text { level } \\
(\mathrm{m})\end{array}$ & $\begin{array}{c}R_{\mathrm{NS}}^{2} \\
\text { calibration } \\
1975-1999\end{array}$ & $\begin{array}{c}R_{\mathrm{NS}}^{2} \\
\text { validation } \\
2000-2011\end{array}$ & $\begin{array}{c}R_{\mathrm{NS}}^{2} \\
\text { validation } \\
2013\end{array}$ \\
\hline Kumara & - & 478000 & 168.83 & - & & \\
Blagoveshchensk & 226 & 493000 & 127.88 & 0.91 & 0.88 & 0.93 \\
Grodekovo & 243 & 726000 & 125.63 & 0.75 & 0.72 & 0.90 \\
Konstantinovka & 335 & 734000 & 115.14 & 0.74 & 0.79 & 0.90 \\
Poyarkovo & 393 & 741000 & 109.4 & 0.78 & 0.83 & 0.92 \\
Innokent'evka & 523 & 837000 & 96.82 & 0.87 & 0.79 & 0.93 \\
Pashkovo & 628 & 856000 & 88.5 & 0.88 & 0.79 & 0.82 \\
Ekaterino-Nikolskoe & 797 & 864000 & 66.62 & 0.77 & 0.68 & 0.89 \\
\hline
\end{tabular}
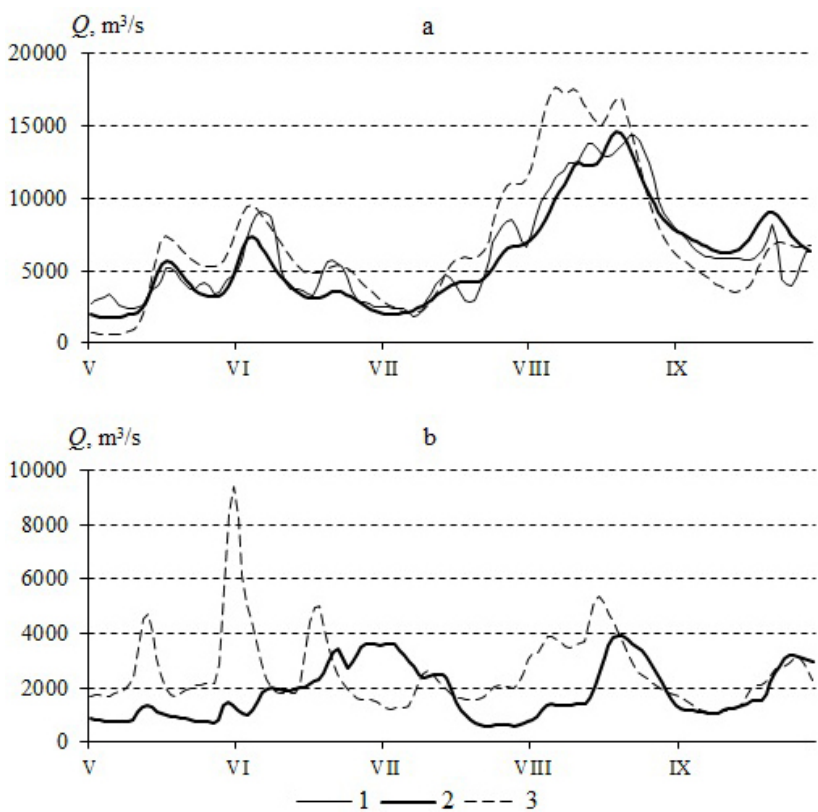

Figure 2. Measured (1) and simulated runoff hydrographs at the mouths of the Zeya (a) and Bureya (b) Rivers in 2013 with (2) and without (3) runoff regulation by existing reservoirs.

reya rivers showed (Fig. 3) that the absence of the Zeya and Bureya reservoirs could lead in 2013 to an increase of water levels at the Middle Amur during the rise of flood wave by $1.7-2.1 \mathrm{~m}$ and at the peak of the flood $-0.4-0.5 \mathrm{~m}$. In this case, the duration of standing water levels above the hazardous level could increase by a factor of 2-3.
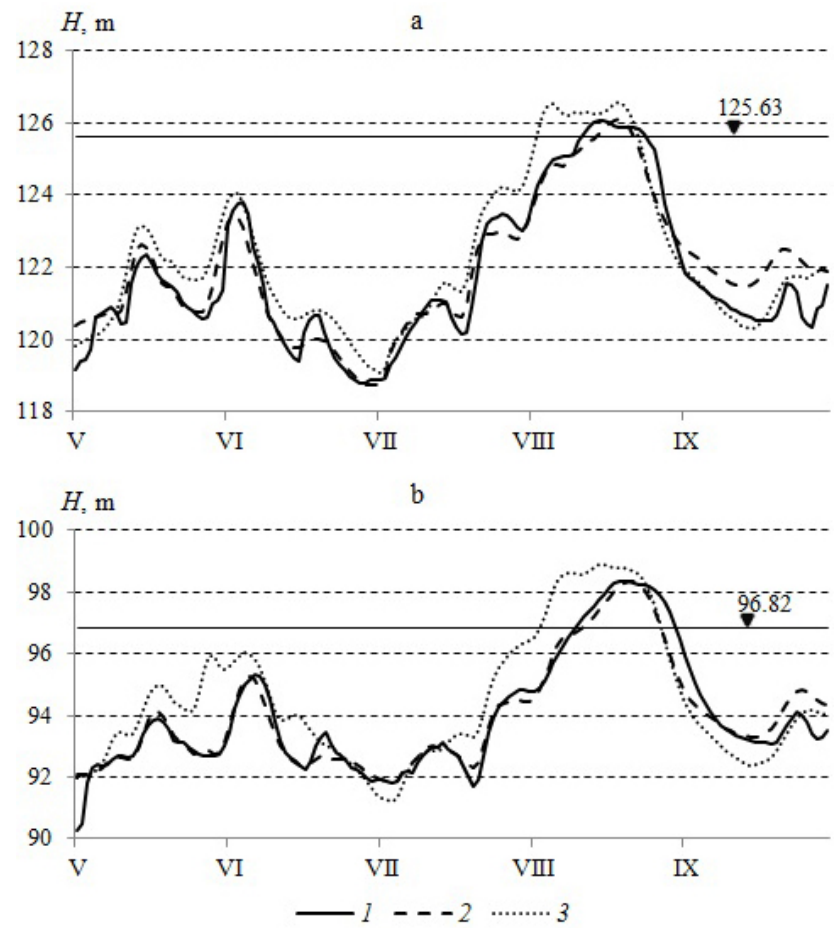

Figure 3. Measured (1) and simulated discharges and water levels in the Amur River in 2013 with (2) and without (3) runoff regulation by existing reservoirs. Gauging stations: (a) Grodekovo; (b) Innokent'evka.

\section{Evaluation of the possible impact of the projected reservoirs in the Zeya and Bureya basins on the hydrological regime of the Middle Amur and its tributaries}

For runoff regulation and flood control in the Middle Amur in the framework of the plan of new waterworks and reservoirs construction different design materials of past years were analyzed, that offers a variety of location options of 
Table 3. Evaluation of the total maximum flood control storage capacity $(W)$ on the Lower-Zeya and Selemdzha reservoirs for the floods of 2013, 1 and $0.1 \%$ probability of exceedance for different combinations of the maximum discharges in the downstream of the waterworks $(Q)$.

\begin{tabular}{|c|c|c|c|c|c|}
\hline \multirow[t]{2}{*}{ No. } & \multicolumn{2}{|c|}{$Q\left(10^{3} \mathrm{~m}^{3} \mathrm{~s}^{-1}\right)$} & \multirow{2}{*}{$\begin{array}{l}W \text { for } \\
\text { rainfall } \\
\text { flood } \\
2013 \\
\left(\mathrm{~km}^{3}\right)\end{array}$} & \multirow{2}{*}{$\begin{array}{l}W \text { for } \\
\text { rainfall } \\
\text { flood of } 1 \% \\
\text { probability } \\
\text { of exceedance } \\
\left(\mathrm{km}^{3}\right)\end{array}$} & \multirow{2}{*}{$\begin{array}{l}W \text { for } \\
\text { rainfall } \\
\text { flood of } 0.1 \% \\
\text { probability } \\
\text { of exceedance } \\
\left(\mathrm{km}^{3}\right)\end{array}$} \\
\hline & $\begin{array}{c}\text { Lower-Zeya } \\
\text { Reservoir }\end{array}$ & $\begin{array}{l}\text { Selemdzha } \\
\text { Reservoir }\end{array}$ & & & \\
\hline 1 & 0 & 0 & 0 & 0 & 0 \\
\hline 2 & 0 & 3 & 0.60 & 0.99 & 2.91 \\
\hline 3 & 0 & 2 & 1.66 & 3.36 & 7.58 \\
\hline 4 & 7 & 0 & 0.50 & 1.10 & 2.30 \\
\hline 5 & 7 & 3 & 1.10 & 2.09 & 5.21 \\
\hline 6 & 7 & 2 & 2.16 & 4.46 & 9.88 \\
\hline 7 & 6 & 0 & 1.61 & 2.81 & 4.4 \\
\hline 8 & 6 & 3 & 2.21 & 3.8 & 7.31 \\
\hline 9 & 6 & 2 & 3.47 & 6.17 & 11.98 \\
\hline
\end{tabular}

new flood control works. As the result of this analysis the following promising new waterworks were selected for future research: Lower-Zeya hydro power plant on the Zeya River, Selemdzha hydro power plant on the Selemdzha River (the largest tributary of the Zeya River) and Lower-Bureya waterwork on the Bureya River, which is under construction (Fig. 1). To more effectively protect the areas from flooding, designers suggest construction of additional flood control storage capacities, which would be used only for the accumulation of rainfall floods. The volume of these capacities is determined by taking into account the land topography and the existing limitations associated with unflooded settlements and economic facilities. In particular, the volume of flood control storage capacity is determined by the characteristics of the rainfall flood of $1 \%$ probability of exceedance and by the maximum discharge through waterwork, which determines reduction of maximum discharges in the downstream.

To assess the effect of the planned flood protection in the Zeya basin, the following scenarios were considered: construction of additional flood control storage capacities on Lower-Zeya reservoir which would provide reduction of maximum discharges at the downstream waterwork to 6000 and $7000 \mathrm{~m}^{3} \mathrm{~s}^{-1}$, and at Selemdzha waterwork - to 2000 and $3000 \mathrm{~m}^{3} \mathrm{~s}^{-1}$. These values are the maximum discharges identified in the project documents.

Simulated by the ECOMAG model the maximum flood control storage capacities of the projected reservoirs at different combinations of maximum discharges in the downstream of the Lower-Zeya and Selemdzha waterworks for scenarios of weather condition of 2013 and for the floods of 1 and $0.1 \%$ probability of exceedance are shown in Table 3. Results of simulation have shown that the runoff regulation only by the Zeya waterwork would reduce the maximum dis- charges at the mouth the Zeya River by $4400 \mathrm{~m}^{3} \mathrm{~s}^{-1}$ for the flood of $1 \%$ probability of exceedance and by $6400 \mathrm{~m}^{3} \mathrm{~s}^{-1}$ - for the flood of $0.1 \%$ probability of exceedance. In case the maximum discharges at the downstream the LowerZeya Reservoir are specified as about 6000-7000 and 2000$3000 \mathrm{~m}^{3} \mathrm{~s}^{-1}$ for the Selemdzha Reservoir, the maximum discharges in the mouth of the Zeya River can be additionally reduced by $\sim 4000$ and $6000 \mathrm{~m}^{3} \mathrm{~s}^{-1}$, respectively, for the floods of 1 and $0.1 \%$ probability of exceedance. The required total flood control storage capacities can reach values of 56 and $8-12 \mathrm{~km}^{3}$, respectively, for the floods of 1 and $0.1 \%$ probability of exceedance (Table 3 ).

As an illustration, on the basis of numerical experiments with the models ECOMAG and MIKE-11 for rough expert estimates an approximate dependence of the total flood control storage capacities of the projected reservoirs in the Zeya basin on requirements to reduce the maximum water level at one of gauging station of the Middle Amur (gauge Grodekovo, Fig. 1) is shown (Fig. 4). Despite the significantly different weather scenarios of rainfall floods in the Zeya river basin, this relationship is rather close. However, more accurate estimates for planning subsequent stages may be given only on the basis of model simulations, as in some cases, different combinations of several flood control storage capacities of the same total value can lead to different effects. The simulated impact of projected reservoirs on the Zeya River extends for hundreds of kilometers below the confluence of the Amur River. 


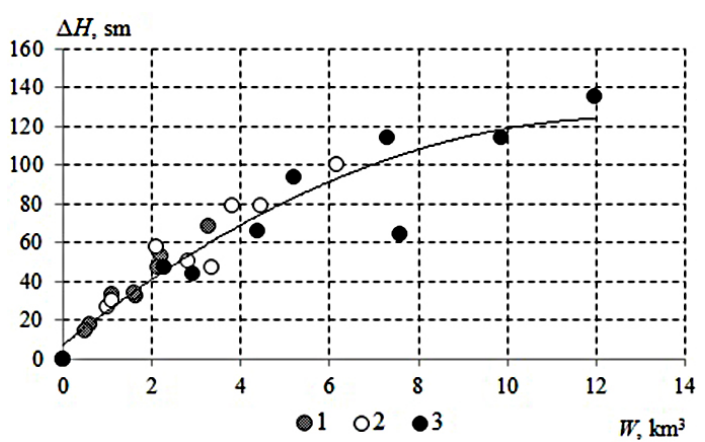

Figure 4. Dependence of water level reduction at Grodekovo gauge on the total flood control storage capacity of the Lower-Zeya and Selemdzha reservoirs: 1 - for weather conditions in 2013, 2 and 3 - scenarios of the floods of 1 and $0.1 \%$ probability of exceedance, respectively.

\section{Conclusions}

Applied for the Middle Amur River basin hydroinformatics technology allows:

- to simulate runoff hydrographs with sufficient accuracy for the Zeya and Bureya River basins and in different cross-sections of $850 \mathrm{~km}$ stretch of the Middle Amur River over many years, including the disastrous flood in 2013 .

- to evaluate the effects of runoff regulation by the existing Zeya and Bureya reservoirs on the hydrologic regime of the rivers in the downstream of waterworks and on the stretch of the Middle Amur from the confluence of the Zeya River to the confluence of the Songhua River. In particular, it was shown that without the Zeya and Bureya reservoirs consequences of flood in 2013 in the Middle Amur basin could be much more disastrous, and the damage - more catastrophic.

- to evaluate the possible effects of runoff management using flood control storage capacities of projected Lower-Zeya and Selemdzha reservoirs on the hydrologic regime of the rivers in the Middle Amur basin for different variants of the maximum discharges in the downstream of the projected waterworks and under different scenarios of meteorological impacts on the watersheds.
At the final stage the simulation results are evaluated according to targets for reducing maximum water levels depending on planned schemes for locating waterworks and their characteristics. If the targets are not reached, then the algorithm of hydroinformatics support (in regional planning decision making) can be repeated with new options of the projected reservoirs placement and their characteristics to achieve optimal performance on hydro-ecological safety and economic feasibility of reservoirs construction.

Acknowledgements. The present work has been carried out within the framework of the Panta Rhei Research Initiative of the International Association of Hydrological Sciences (IAHS).

\section{References}

Danilov-Danilyan, V. I., Gelfan, A. N., Motovilov, Y. G., and Kalugin, A. S.: Disastrous Flood of 2013 in the Amur Basin: Genesis, Recurrence Assessment, Simulation Results, Water Resources, 41, 115-125, 2014.

Gelfan, A. N. and Motovilov, Y. G.: Developing methods of flood risk assessment and long-term flood forecasting on the basis of dynamic-stochastic model, in: River runoff: spatial-temporal variability and hydrological extremes, edited by: Alexeevsky, N. I., Publ. Moscow State University, Moscow, 145-164, 2014.

Motovilov, Y. G., Gottschalk, L., Engeland, K., and Belokurov, A.: ECOMAG - regional model of hydrological cycle, Application to the NOPEX region, Institute Report Series no. 105, Department of Geophysics, University of Oslo, Oslo, 88 pp., 1999a.

Motovilov, Y. G., Gottschalk, L., Engeland, K., and Rodhe, A.: Validation of a distributed hydrological model against spatial observation, Agr. Forest Meteorol., 98-99, 257-277, 1999b.

Petersen, G.: Managing extreme flood events, Heft 9, IHP/HWRPBerichte, Koblenz, 103 pp., 2009. 